\title{
GEOLOGY, MINERALOGY AND RADIOACTIVITY STUDIES OF WADI KHUDA STREAM SEDIMENTS, SOUTH EASTERN DESERT, EGYPT
}

\section{HASSAN, A. A. SHAHIN, A.EL AZAB AND MASOUD S.MASOUD}

Nuclear Materials Authority, P. O. Box 530, El-Maadi, Cairo, Egypt

\section{ABSTRACT}

This study concerned with the geologic features, mineralogical composition and radioactivity of Wadi Khuda stream sediments south Eastern Desert of Egypt. Geologically, the basement rocks cropping out at Wadi Khuda area are gneisses, gabbrodiorite complex, tonalite-granodiorite, monzogranite and albite granite. The area is drained by several Wadis as Wadi Khuda, Wadi Hindia, Wadi Shut and Wadi Salib el Abiad. The stream sediments samples indicate significant enriched in some HFSE (high field strength elements) such as $\mathrm{Zr}, \mathrm{Y}, \mathrm{Nb}$ compared to the probable source rocks. This indicate that these trace elements in the stream sediments derived from the muscovite granite and granitic pegmatities.

Mineralogical studies on the heavy minerals of Wadi Khuda recorded by magnetite, ilmenite, zircon, thorite, titanite, fluorite, and garnet. The radiometric measurements of the studied stream sediments show that eU varies from 3 to 16 ppm with an average of $7.6 \mathrm{ppm}$, while eTh ranges from 6 to $40 \mathrm{ppm}$ with an average of $21.5 \mathrm{ppm}$. The average concentration of Ra and K\% are 4.2 ppm and $1.8 \%$ respectively.

Keywords: Mineralogy, Stream sediments, Wadi Khuda

\section{INTRODUCTION}

In stream sediments, a whole range of known mineral can be found i.e. heavy minerals are the most important group. Heavy minerals are known to occur in igneous, metamorphic and sedimentary rocks. These minerals are stable and of high specific gravity and are of economic importance in case of sufficient concentrations in large tonnage. The occurrence and abundance of heavy minerals suits are influenced by various factors such as specific gravity and hardness of individual minerals. Some minerals such as magnetite, tourmaline, zircon, rutile and sphene can form authigenically in sediments.

Wadi Khuda area is situated in the southern part of the Eastern Desert of Egypt. It is bounded by Latitudes $23^{\circ} 34^{\prime} 29^{\prime}-23^{\circ} 49^{\prime} 15^{\prime \prime} \mathrm{N}$ and Longitudes $35^{\circ} 01^{\prime} 59^{\prime \prime}-35^{\circ} 32^{\prime} 44^{\prime \prime} \mathrm{E}$ (Figur1).

The study area is characterized by exposed mount area as gabbroic and granitic rocks. The important mountains are Gabal Shinshif, (580m a.s.1.); Gabal Um Etli, (763 m a.s.1.), Gabal Um Akrah(1049m a.s.1.) and Gabal Qubur (927m a.s.1.). The important one are Wadi Khuda running NE-SW draining in the Red Sea and Wadi Shut is the a tributary of Wadi Khuda, draining at the northwest direction.

The area was studied topographically, geologically and chemically by several authors,
Hume (1934) reported the presence of serpentines on the northern side of wadi Kallalate. Hunting (1967) differentiated the Batoga granite from the surrounding synorogenic granitoids (grey granite) and geosynclinals volcanics. ELAlfy et al. (1994) geochemically explored the Elba-El Gerf area and mentioned that there are a several of target setes that in which recorded several anomalies of copper, nickel and chromium. EGSMA (1992) (internal report) studied the area around Wadi Khuda where metamorphic and magmatic rocks are exposed. The metamorphic rocks include gneisses, while magmatic rocks include gabbro-diorite complex, tonalitegranodiorite, monzogranite and albite granite. El Afandy et al. (2006) studied the heavy minerals of beach placers south Ras Banas.They recorded total heavy mineral amounts ranging from $9.97 \%$ to $94.6 \%$ with an average of $29.2 \%$. Some black sand lenses composedof more than 55\% heavy minerals are recorded. The economic minerals in the bulk sand are represented by $1.36 \%$ magnetite, $0.78 \%$ ilmenite, $0.021 \%$ leucoxene, $0.024 \%$ garnet, $0.182 \%$ zircon, $0.01 \%$ rutile and $0.0002 \%$ monazite beside $0.064 \%$ titanite. Magnetite and ilmenite constitute more than $93 \%$ of the total economic minerals.

Recently, Raslan et al. (2010), studied mineralogy and radioactivity of pegmatites from south Wadi Khuda area. They concluded that 
mineralogical investigations of the studied pegmatites revealed the presence of secondary uranium minerals (kasolite and autunite), in addition to zircon, thorite, apatite, garnet and biotite. Primary and secondary radioactive mineralizations indicated that the mineralization is not only magmatic, but also post-magmatic.

The main objectives of the present study are to study and investigate the heavy minerals of stream sediments from Wadi Khuda.

\section{Materials and Methodology of Study}

A total of 15 channel samples each about $10 \mathrm{~kg}$ were collected from the area from boreholes of diameter $50 \mathrm{~cm}$, and $0.80-1 \mathrm{~m}$ depth, with intervals ranging from 1.75 to $4.85 \mathrm{~km}$ (Figure 1). The air-dried original sample was screened using $2 \mathrm{~mm}$. The obtained less than $2 \mathrm{~mm}$ fractions were quartered using June's splitters of different chutes down to about $250 \mathrm{gm}$.

A representative sub-sample weighing about $60 \mathrm{gm}$ was taken from each prepared sample by quartering for heavy mineral separation. Separation was conducted using bromoform ( $\mathrm{Sp}$. Gr. $2.86 \mathrm{~g} / \mathrm{cm} 3$ ) and magnetic fractionation using a Frantz Isodynamic Magnetic Separator (Model L-1). The obtained fractions were carefully studied using the Binocular Stereomicroscope.

In the present study, the collected 15 stream sediment samples were analyzed for some trace elements. The elements were determined by XRF techniques on pressed powder pellets. Mineralogical identification of the mineral constituents of the stream sediments was carried out by X-ray diffraction technique. A Phillips X-ray diffractometer (Model PW-1010) with a scintillation counter (Model PW-25623/00) and Ni filter was used.Semiquantitative EDX chemical analyses were carried out using a Phillips XL-30 Environmental Scanning Electron Microscope (ESEM).

The used cylindrical plastic containers, is of volume $212.6 \mathrm{~cm} 3,9.5 \mathrm{~cm}$ average diameter, and $3 \mathrm{~cm}$ length. Then the container was filled with 300-400 gm of the samples, tightly sealed, and left for 30 days to accumulate free radon and attain radioactive equilibrium. The four standards $\mathrm{eU}$, eTh, Ra, and $\mathrm{K}$ were measured twice, 1000 seconds for each; the average of gross counts was taken, then divided by their net weight, and in- troduced to a computer program (Matolin,1990), which runs under Ms-Dos to be used as a matrix of sensitivities represented as the concentrations of eU, eTh, Ra and K. These concentrations are used as a reference for the studied samples. The latter were measured in the same way by means of the computer program which gives out the concentrations of eU and eTh in ppm.

\section{Stream Sedements Variation In Elevation Of The Sampling Sites}

The Stream sediment samples were collected from the up to down stream to represent the weathering products of the various rock units exposed in the area of W. Khuda (Figure 2), and (Table 1). The upstream show high elevated of the sampling at sites No. $1 \& 2$ are $460 \mathrm{~m}$ and $415 \mathrm{~m}$ (a.s.1.) respectively, while at downstream at sites samples No. $1 \& 2$ are $85 \mathrm{~m}$ and $90 \mathrm{~m}$ (a.s.1.) espectively.

\section{GEOLOGIC SETTING}

The exposed rock types in the concerned area include gneisses, gabbro-diorite complex, tonalite-granodiorite, biotite, muscovite and albite granites. The detailed geologic map of Wadi Khuda area is present in (Figure 3).

Figure 3 Geologic map of Wadi Khuda area showing the location of the collected samples in the study area, modified after EGSMA (1992).

\section{Gneisses}

The gneisses occur in the central part of the mapped area along Wadi Khuda (Figure 4a). Lithologically, the gneisses are mainlycomposed of quartz-mica gneisses with bands of hornblende gneisses and amphibolites. The gneisses are highly deformed and foliated. The general trend of foliation is NW-SE dipping at with low and moderate of angles to NE and SW. The gneisses suffered high grade regional metamorphism resulting in formation of local migmatization. The migmatizes are coarse-grained to pegmatitic grain size and are coarsely banded, made up of mesosome, melanosome and leucosome bands. Field relation indicates that gabbro-diorite complex and tonalite-granodiorite intruded it with intrusive sharp contact (Figure 4b).

\section{Gabbro-diorite complex}

These rocks are cccupy a large area in the 
study area occuring as huge batholith intruding the older rocks gneisses. They crop out in the northern and southern parts of Wadi Khuda. They show nearly horizontal concordant against gneisses. They are medium to coarse grained, grayish green to dark gray in colour, massive in some parts and intensively weathered in others.

The rocks are intensively jointed by two sets of joints, NW-SE dipping $70^{\circ} \mathrm{E}$. and NE-SW dipping $54^{\circ} \mathrm{N}$. Field relations indicate that these rocks are intruded by the tonalite-granodiorite with sharp contact (Figure 4c ).

\section{Tonalite-granodiorites}

These rocks crop out as a large extention in the northern part of the mapped area. They form low to moderate hills and small isolated masses extruded by basic dykes. They are gray to dark gray in colour, medium to coarse-grained, rich in mafic minerals and in some parts show xenoliths of the pre-existing rocks. The tonalite-granodiorites are generally of massive hard nature, but in some places are highly weathered and deformed reaching mylonite specially near the contact with older rocks, which ones are highly fractured and dissected by several sets of joints. These rocks are intruding the gneisses and gabbro-diorites complex and intruded by muscovite granite with sharp contact (Figure 4d).

\section{Biotite granite}

Biotite granite is of limitied extention forming moderate to high hills south Wadi Khudda. This rock is pale pink to pink color, medium to coarse grained and composed of quartz, K-feldspar and biotite. Field study indicates that these rocks are intruded by muscovite granite (Figure $4 \mathrm{e})$.

\section{Muscovite granite}

Muscovite granite occurs at the entrance and south WadiKhuda.It is coarse to very coarse grained and usually massive,range in color from pink to pinkish white. Field relations indicate that these rocks are intruded gneiss and biotite granite with sharp contact (Figure 4e).

\section{Albite granite}

Albite granite is very limited occurrence as small size dyke-like body and plug-like bodies, cutting along the tonalite-granodiorite forming high ridge resistant against weathering.
It is very coarse white in color. It is abundant in the pegmatitic veins containing large crystals of feldspar, quartz and muscovite.

\section{Granitic pegmatites}

Granitic pegmatities are very coarse of pegmatitic fatures. It occurs as dyke-like body, pink to deep pink in color intruding the tonalitegranodiorite, biotite granite and muscovite granite (Figure 3).

\section{Pegmatites}

Pegmatites are commonly encountered in the study area. They are found as dykes and small bodies with dimensions ranging from 2 to $5 \mathrm{~m}$ in width and 10 to $50 \mathrm{~m}$ in length.. These rocks are very coarse-grained, mainly recorded in the muscovite granite near the contact with the older granitoids. They are composed mainly of megacrysts of potassic feldspar and quartz together with small pockets of muscovite (Figure $4 \mathrm{f}$ ).

\section{Mineral Composition of Stream Sediments}

\section{Heavy minerals distribution}

The average content of the heavy minerals in the studied stream sediments is $3.85 \%$ ranging from $0.47 \%$ to $9.18 \%$ (Tables $2 \& 3$ ). The content of the heavy minerals in the studied stream sediments increases from southwest (upstream) to northeast (downstream).

The weight percentage of each concerned mineral relative to the corresponding original sample was calculated according to Stakhove equation:

$$
\mathrm{Q}=\left[\mathrm{P} . \mathrm{n}_{\mathrm{m}} \cdot \mathrm{d}_{\mathrm{m}} / \Sigma\left(\mathrm{n}_{\mathrm{o}} \mathrm{d}_{\mathrm{o}}\right)\right] \cdot 100
$$

Where: $\mathrm{Q}=$ the weight percentages of the concerned mineral

$\mathrm{P}=$ the weight percentage of the corresponding magnetic fraction.

$\mathrm{n}_{\mathrm{m}}=$ the number of grains of the mineral.

$\mathrm{d}_{\mathrm{m}}=$ specific gravity of the mineral.

$\Sigma\left(n_{0} d_{0}\right)=$ the sum of the number of grains for each mineral multiplied by its specific gravity.

\section{Magnetite $\left(\mathrm{Fe}_{2} \mathrm{O}_{4}\right)$}

Magnetite was picked by hand magnet from the studied samples, and important of iron ore. It is characterized by an opaque with metallic luster very heavy, no-cleavage, and black in color, shiny, rounded to subrounded grains and strongly magnetic (Figure 5a). It is perfect octahedron 
or dodecahedron with striated faces. Frequently in mafic and ultramafic extrusive rocks as differentiation product during the magmatic stage. It is rare in pegmatite and hydrothermal veins.

\section{Ilmenite_([FeTiO $]$ ])}

It is opaque commonly angular grains with submetallic luster, no-cleavage and black in colors or dark brown rhombohedral (Figure 5b). It is common in plutonic rocks as ahigh temperature, occur in pegmatite and metamorphic rocks as gneisses. Ilmenite is the most abundant Fe-Ti oxide mineral.

\section{Garnet [ $\left.\mathrm{Fe}_{3} \mathrm{Al}_{2}\left(\mathrm{SiO}_{4}\right)\right]$}

Garnet which crystallizes in the isometric system, is mainly formed of angular to subrounded particles. Its grain size is relatively coarser than the other economic minerals of the study samples.Garnet is the pale pink color (Figure 5c), and has moderate magnetic susceptibility which varies slightly according to variation in chemical composition (Milner, 1962).

\section{Sphene (Titanite) [CaTiSiO $\left.{ }_{5}\right]$}

Titanite mineral grains are subhedral to anhedral of adamantine luster. It exhibits transparent to translucent yellow to yellowish brown colors (Figure 5d).

\section{Fluorite $\left(\mathrm{CaF}_{2}\right)$}

Flouriteis recorded in mineralized granite and pegmatite. Fluorite containing high uranium content may be attributed to fluorine ions which forms a complex with uranium. Uranus fluoride complexes are important in transporting $\mathrm{U}$ at low temperature at typical fluoride concentrations in acidic reducing ground waters (Langmuir, 1978). Any available $\mathrm{Ca}^{+2}$ will lead to the formation of fluorite and prevention of uranium migration.It is occurs as transparent to translucent crystals that color is white (Figure 6a).

\section{Zircon $\left[\mathrm{ZrSiO}_{4}\right]$}

It occurs as euhedral grains of honey yellow, red, black and grey colors of adamantine luster., zircon well preserved as euhedral crystals with bipyramidal termination while few zircon grains are prismatic crystals forms (Figure 6b).

\section{Samarskite(Oxides and Hydroxides) \{$$
\text { (Y,Ce,U,Ca,Pb) (Nb,Ta,Sn) } \left.{ }_{2} \mathbf{O}_{6}\right\}
$$

The crystals are rectangular prisms, striated, velvety-black with brown surface alteration. Also it present as fracture filling in deformed zir- con crystal. Samarskite present in shear zone and down stream samples. It detected using EDX technique (Figure 6c ).

\section{Thorite [ $\left.\mathrm{ThSiO}_{4}\right]$}

Thorite occurs in natural as a primary mineral chiefly in pegmatites. It also occurs as an accessory mineral in black sands and other detrital deposits derived from gneissic or granitic terranes. It occurs associated with zircon, sphene, monazite, xenotime, allanite, and various niobate-tantalates.

It occurs as brownish black to black opaque grains of greasy luster (Figure 6d). Most of thorite mineral grains are subhedral to anhedral corroded and cracked. Rarely, euhedral prismatic thorite grains are present. They are strongly metamictized, as determined by $\mathrm{X}$-ray diffraction. Thorite was annealed at $1100^{\circ} \mathrm{C}$ for approximately four hours preceding identification by XRD. The obtained data (Table4) reveal the presence of thorite peaks (ASTM card 11-419) in addition to hematite peaks. The presence of hematite may be in the form of thin films coating thorite grains or as individual hematite grains.

The results of XRF analysis of the trace elements for the stream sediments samples and the surrounding bedrocks only muscovite granite and granitic pegmatitiesare tabulated in (Table $5 \& 6$ ). The Table shows that, the stream sediments samples are rich in $\mathrm{Zr}$, and Y.This clear that, the stream sediments are highly affected by the surrounding rocks. The distribution and lateral distribution of $\mathrm{Zr}$ and $\mathrm{Y}$ elements are shown (Figures 7a, 7b, 8a, and 8b). From these maps we can concluded that the concentration of $\mathrm{Zr}$ and $\mathrm{Y}$ increases in the centeral part of the area around the muscovite granites, and biotite granite. The distribution maps shows increasing the $\mathrm{Zr}$ and $\mathrm{Y}$ from up-stream to down-stream.

Geochemical data of the bedrocks only the muscovite granite and granitic pegmatities will be correlate with the elemental content in stream sediments. Only some trace elements such as $\mathrm{Zr}$, YandNb roughly correlate with the chemical composition of the probable source rocks (muscovite granite and granitic pegmatities). Some of the HFSE (high field strength elements) (Zr, $\mathrm{Y}, \mathrm{Nb}$ ) are highly enriched in the stream sediments samples compared to the probable source 
rocks. This indicates the presence of HFSE-rich mineral sources such as granitic pegmatites in the drainage area. Chondrite-normalised incompatible multi-element spider diagrams for the stream sediments samples roughly correlate with the chemical composition of the probable source rocks (muscovite granite and granitic pegmatities) (Figures 9 and 10). These figures show that both the bedrocks which include the muscovite granite and granitic pegmatities and the stream sediments samples are enriched in some HFSE (high field strength elements) ( $\mathrm{Zr}, \mathrm{Y}, \mathrm{Nb}$ ), but strongly depleted in $\mathrm{Ni}$ and $\mathrm{Cr}$.

\section{Radiometric Survey}

A total of (15) stream sediment samples had been collected from the studied area throughout systematic sampling to determine their eU, Th, $\mathrm{Ra}$ and $\mathrm{K}$ contents. The obtained results from the radiometric measurements of the studied stream sediments are listed in (Table 7).

The eU examined in the stream sediments of Wadi khudah ranges from 3 to $16 \mathrm{ppm}$ (Figure 11a), while eTh ranging from 6 to $40 \mathrm{ppm}$ (Figure $11 \mathrm{~b}$ ), Ra ranging from 3 to $7 \mathrm{ppm}$ and $\mathrm{K}$ ranging from $1.1 \%$ to $2.8 \%$.

Ivanovich (1994) concluded that, a relatively constant eTh/eU mass ratio of around 3.5 is found in most natural systems, while the corresponding value obtained for this ratio ranging from 1.3 to 6.7 . It indicates that there is a significant fractionation during weathering of these sediments causing the increasing or depletion of uranium in some samples.

The main factors controlling the distribution of radioelements in sediments are the geomorphological features of the basin of deposition, radioelements content of the source rocks, grain size of these sediments, the alkalinity of the surface groundwater, and to a lesser extent the effect of the organic matter.

\section{eU versus eTh variation diagram}

The relation between $U$ and Th may indicate the enrichment or depletion of $U$ because $T h$ is normally stable. Thorium is three times as abundant as uranium in all rock types. When this ratio is disturbed, it indicates either depletion or en- richment of uranium.

The eU against eTh variation diagram for the studied samples is shown in (Figure 11c), which indicates strong positive relationships between these two elements. These results explain the low alteration processes affecting on these samples, and also indicates that magmatic processes played an important role in the uranium enrichment of these granites which represent the source of these sediments.

\section{eU vs eTh/eU variation diagram}

The bivariate diagram of eU against eTh/eU is shown in (Figure 11d). This diagram, clear negative relationships for the studied samples. This relation may be either attributed to the mobilization of uranium in the studied samples.

\section{eTh versus eTh/eU variation diagram}

The relation between $\mathrm{eTh}$ and $\mathrm{eTh} / \mathrm{eU}$ ratios is shown in (Figure 11e) for the studied samples. This Figure shows a scatter pattern which may be due to the effect of mobilization of (U) and concentration of $(\mathrm{Th})$.

\section{eU versus $\mathrm{Zr}$ variation diagram}

The eU versus $\mathrm{Zr}$ variation diagram shows strong positive correlation in the studied samples (Figure 11f). The uranium and zirconium enrichment in the studied samples, supports the concept that $U$ was trapped in the accessory minerals as zircon.

\section{CONCLUSION}

Geologic study of Wadi Khuda surrounding rocks revealed that seven bedrock lithology forming most of the rock units at WadiKhuda. These rock unites include gneiss, gabbro-dioritr complex, tonalite-granodiorite, biotite granite, muscovite granite,albite granite and pegmatitic granite.

Chondrite-normalised incompatible multi-element pattern for stream sediments samples indicate significant enriched in some HFSE (high field strength elements) such as $\mathrm{Zr}, \mathrm{Y}, \mathrm{Nb}$ compared to the probable source rocks. This indicate that these trace elements in the stream sediments derived from muscovite granite and granitic pegmatities

Mineralogical studies on the stream sediments of Wadi Khuda revealed that the heavy 
minerals content ranging from $0.47 \%$ to $9.18 \%$ with an average $3.85 \%$, while magnetite constitutes has an average of $1.19 \%$. The most impor- tant heavy minerals observed in the stream sediments of Wadi Khuda include ilmenite $0.25 \%$, titanite $0.037 \%$, garnet $0.35 \%$, zircon $0.15 \%$ andthoriteand samarskite $0.022 \%$. The abundance
Table1:Distance and elevation of the studied stream samples at Wadi Khuda.

\begin{tabular}{|c|c|c|}
\hline Sample No. & Distance (km) & Elevation (a.s.l.) (m) \\
\hline 1 & 0.00 & 460 \\
\hline 2 & 2.30 & 415 \\
\hline 3 & 7.15 & 375 \\
\hline 4 & 11.50 & 365 \\
\hline 5 & 16.00 & 320 \\
\hline 6 & 18.00 & 280 \\
\hline 7 & 19.75 & 295 \\
\hline 8 & 21.75 & 250 \\
\hline 9 & 23.80 & 240 \\
\hline 10 & 25.90 & 215 \\
\hline 11 & 29.90 & 200 \\
\hline 12 & 31.75 & 160 \\
\hline 13 & 34.00 & 130 \\
\hline 14 & 36.75 & 90 \\
\hline 15 & 40.00 & 85 \\
\hline
\end{tabular}

Table 2: The percentages of the heavy minerals in the studied stream sediments of Wadi Khuda

\begin{tabular}{|c|c|}
\hline $\begin{array}{c}\text { Sample } \\
\text { No }\end{array}$ & $\begin{array}{c}\text { Heavy } \\
\text { minerals } \%\end{array}$ \\
\hline 1 & 2.2 \\
\hline 2 & 2.44 \\
\hline 3 & 9.18 \\
\hline 4 & 7.43 \\
\hline 5 & 7.54 \\
\hline 6 & 6.6 \\
\hline 7 & 6.15 \\
\hline 8 & 6.86 \\
\hline 9 & 2.87 \\
\hline 10 & 2.17 \\
\hline 11 & 1.38 \\
\hline 12 & 0.76 \\
\hline 13 & 0.75 \\
\hline 14 & 0.92 \\
\hline 15 & 0.47 \\
\hline
\end{tabular}

Table 3: The weight percentages of the concerned heavy minerals in the Wadi Khuda stream sediment.

\begin{tabular}{|c|c|c|c|c|c|c|c|c|}
\hline $\begin{array}{l}\text { S. } \\
\text { No. }\end{array}$ & $\begin{array}{c}\text { Mag. } \\
\%\end{array}$ & $\underset{\%}{\text { Ilm. }}$ & $\begin{array}{c}\text { Gar. } \\
\%\end{array}$ & $\begin{array}{c}\text { Tita. } \\
\text { \% }\end{array}$ & Zr. \% & $\begin{array}{c}\text { Thr.\& } \\
\text { Sam.\% }\end{array}$ & $\begin{array}{c}\text { Flou. } \\
\%\end{array}$ & $\begin{array}{l}\text { Amph. } \\
\text { \&Pyr. } \\
\%\end{array}$ \\
\hline 1 & 1.0 & 0.13 & 0.10 & 0.03 & 0.07 & 0.02 & 0.01 & 0.86 \\
\hline 2 & 1.1 & 0.18 & 0.12 & 0.06 & 0.16 & 0.03 & 0.01 & 0.78 \\
\hline 3 & 2.94 & 0.13 & 0.62 & 0.08 & 0.34 & 0.08 & 0.2 & 4.79 \\
\hline 4 & 1.85 & 0.76 & 0.57 & 0.07 & 0.37 & 0.07 & 0.1 & 3.64 \\
\hline 5 & 1.71 & 0.71 & 0.23 & 0.05 & 0.35 & 0.04 & 0.15 & 4.3 \\
\hline 6 & 1.60 & 0.65 & 0.29 & 0.08 & 0.24 & 0.04 & 0.1 & 3.6 \\
\hline 7 & 1.92 & 0.15 & 0.61 & 0.06 & 0.29 & 0.02 & 0.2 & 2.9 \\
\hline 8 & 2.12 & 0.13 & 0.71 & 0.08 & 0.25 & 0.01 & 0.2 & 3.3 \\
\hline 9 & 1.11 & 0.08 & 0.13 & 0.01 & 0.047 & 0.01 & 0.01 & 1.47 \\
\hline 10 & 1.08 & 0.06 & 0.48 & 0.01 & 0.04 & 0.001 & 0.002 & 0.50 \\
\hline 11 & 0.51 & 0.07 & 0.54 & 0.01 & 0.02 & 0.002 & 0.003 & 0.22 \\
\hline 12 & 0.27 & 0.05 & 0.32 & 0.01 & 0.01 & 0.001 & 0.001 & 0.1 \\
\hline 13 & 0.24 & 0.15 & 0.13 & 0.002 & 0.03 & 0000 & 0.001 & 0.2 \\
\hline 14 & 0.21 & 0.41 & 0.28 & 0.003 & 0.01 & 0000 & 0.001 & 0.41 \\
\hline 15 & 0.19 & 0.11 & 0.05 & 0.002 & 0.02 & 0000 & 0.001 & 0.1 \\
\hline Min. & 0.19 & 0.05 & 0.05 & 0.002 & 0.01 & $\mathbf{0}$ & 0.001 & 0.1 \\
\hline Max. & 2.94 & $\cdot 76$ & 0.71 & 0.08 & 0.37 & 0.08 & 0.2 & 4.79 \\
\hline Ave. & 1.19 & 0.25 & 0.35 & 0.37 & 0.15 & 2 & 0.07 & 1.18 \\
\hline
\end{tabular}


GEOLOGY, MINERALOGYAND RADIOACTIVITY STUDIES OF WADI KHUDA

Table 4: X-ray diffraction data of the annealed thorite from the studied stream sediments.

\begin{tabular}{|c|c|c|c|}
\hline $\begin{array}{c}\text { Analyzed } \\
\text { Sample }\end{array}$ & \multicolumn{2}{c|}{$\begin{array}{c}\text { Thorite } \\
\text { ATM card } \\
(11-419)\end{array}$} \\
\hline dA & I/Io & dA & I/Io \\
\hline 4.71 & 62 & 4.72 & 85 \\
\hline 3.56 & 100 & 3.55 & 100 \\
\hline 2.87 & 25 & 2.842 & 45 \\
\hline 2.67 & 35 & & \\
\hline 2.68 & 48 & 2.676 & 75 \\
\hline 2.54 & 26 & 2.516 & 30 \\
\hline 2.35 & 5 & 2.361 & 5 \\
\hline 2.20 & 30 & 2.222 & 30 \\
\hline 2.04 & 5 & & \\
\hline 2.03 & 15 & 2.019 & 20 \\
\hline 1.89 & 17 & 1.885 & 30 \\
\hline 1.82 & 31 & 1.834 & 65 \\
\hline 1.78 & 18 & 1.782 & 20 \\
\hline 1.64 & 14 & & \\
\hline 1.64 & 8 & 1.667 & 10 \\
\hline 1.44 & 6 & 1.484 & 20 \\
\hline 1.35 & 4 & 1.444 & 15 \\
\hline
\end{tabular}

Table 5: XRF Analysis of stream sediments samples at Wadi Khuda.

\begin{tabular}{|c|c|c|c|c|c|c|c|c|c|c|c|c|c|}
\hline S. No. & Cr & Ni & Cu & Zn & Zr & Rb & Y & Ba & Pb & Sr & Ga & V & Nb \\
\hline 1 & 231 & 124 & 64 & 183 & 1207 & 142 & 245 & 100 & 127 & 76 & 4 & 29 & 48 \\
\hline 2 & 214 & 132 & 62 & 132 & 1270 & 163 & 252 & 103 & 112 & 89 & 3 & 32 & 44 \\
\hline 3 & 225 & 140 & 70 & 255 & 3470 & 258 & 265 & 114 & 125 & 121 & 3.4 & 35 & 51 \\
\hline 4 & 210 & 143 & 72 & 262 & 3260 & 255 & 257 & 112 & 123 & 150 & 3.3 & 36 & 52 \\
\hline 5 & 212 & 142 & 68 & 288 & 3252 & 248 & 255 & 110 & 122 & 142 & 3.6 & 30 & 50 \\
\hline 6 & 218 & 134 & 63 & 250 & 2250 & 234 & 253 & 105 & 117 & 156 & 3.8 & 29 & 43 \\
\hline 7 & 210 & 132 & 71 & 251 & 2010 & 229 & 260 & 95 & 115 & 174 & 3.2 & 28 & 40 \\
\hline 8 & 200 & 142 & 69 & 245 & 2005 & 205 & 262 & 98 & 112 & 135 & 3.0 & 26 & 38 \\
\hline 9 & 178 & 110 & 55 & 131 & 350 & 141 & 128 & $\mathbf{8 5}$ & $\mathbf{9 2}$ & 126 & 2.1 & 21 & 32 \\
\hline 10 & 165 & 105 & 40 & 170 & 340 & 143 & 124 & $\mathbf{8 2}$ & 90 & 122 & 2.2 & 20 & 26 \\
\hline 11 & 175 & 112 & 50 & 155 & 331 & 131 & 110 & 78 & $\mathbf{8 2}$ & 107 & 2.1 & 19 & 27 \\
\hline 12 & 142 & 108 & 55 & 145 & 295 & 127 & 118 & 71 & 76 & 90 & 1.5 & 18 & 25 \\
\hline 13 & 119 & 112 & 49 & 130 & 250 & 121 & 114 & 70 & 71 & 89 & 2.0 & 13 & 24 \\
\hline 14 & 111 & 120 & 47 & 118 & 231 & 116 & 111 & 68 & 68 & 75 & 1.1 & 12 & 21 \\
\hline 15 & 100 & 112 & 41 & 116 & 214 & 114 & 110 & 65 & 62 & 66 & 1.4 & 10 & 20 \\
\hline
\end{tabular}

Table 6: XRF Analysis of the muscovite granite and granitic pegmatities at Wadi Khuda.

\begin{tabular}{|c|c|c|c|c|c|c|c|c|c|c|}
\hline \multirow{2}{*}{ S. No. } & \multicolumn{9}{|c|}{ Muscovite granite } & \multicolumn{3}{|c|}{$\begin{array}{c}\text { Granitic } \\
\text { pegmatities }\end{array}$} \\
\cline { 2 - 11 } & KH12 & KH13 & KH14 & KH15 & KH16 & KH17 & KH18 & KH19 & KH21 & KH22 \\
\hline Cr & $<$ L.D & $<$ L.D & $<$ L.D & $<$ L.D & $<$ L.D & $<$ L.D & $<$ L.D & $<$ L.D & $<$ L.D & 5.09 \\
\hline Ni & $<$ L.D & 7.53 & $<$ L.D & 7.62 & $<$ L.D & $<$ L.D & $<$ L.D & 6.75 & 7.93 & $<$ L.D \\
\hline Cu & $<$ L.D & $<$ L.D & 7.38 & $<$ L.D & $<$ L.D & 15.63 & 20.41 & $<$ L.D & $<$ L.D & $<$ L.D \\
\hline Zn & 15.57 & 23.2 & 31.37 & 13.64 & 13.21 & 16.4 & 12.89 & 10.87 & 46.52 & 38.1 \\
\hline Zr & 23.51 & 28.27 & 25.25 & 24.13 & 26.92 & 21.93 & 21.26 & 23.14 & 61.43 & 60.69 \\
\hline Rb & 91.55 & 71.79 & 119.1 & 82.76 & $\mathbf{8 2 . 5 5}$ & $\mathbf{8 2 . 6 9}$ & $\mathbf{8 6 . 6 7}$ & $\mathbf{6 9 . 8 8}$ & 163.16 & 151.42 \\
\hline Y & 10.48 & 18.3 & 11.84 & 11.03 & 10.93 & 10.74 & 12.87 & 12.4 & 75.68 & 67.29 \\
\hline Ba & 43.54 & 29.65 & 16.63 & 36.40 & 43.53 & 93.57 & 119.94 & 31.21 & 10.27 & 8.04 \\
\hline Pb & 12.23 & 11.4 & 11.12 & 16.45 & 15.76 & 16.95 & 17.50 & 14.11 & 26.57 & 25.64 \\
\hline Sr & 28.85 & 24.16 & 12.21 & 28.94 & 33.34 & 39.75 & 44.04 & 28.52 & 2.00 & 4.03 \\
\hline Ga & 24.06 & 23.40 & 28.43 & 26.28 & 23.60 & 25.90 & 24.46 & 24.59 & 23.59 & 22.97 \\
\hline V & 3.95 & $<$ L.D & $<$ L.D & 5.51 & 3.66 & 7.27 & 6.27 & 5.47 & $<$ L.D & $<$ L.D \\
\hline Nb & 7.77 & 5.13 & 7.48 & 5.57 & 5.1 & 5.56 & 4.91 & 6.06 & 7.89 & 14.62 \\
\hline
\end{tabular}

$<$ L.D = Under limit of detection 
Hassan, A. A et al .

Table7: The distribution of radiomtric measurements of the studied stream sediments samples

\begin{tabular}{|c|c|c|c|c|c|}
\hline Sample No. & eU (ppm) & eTh (ppm) & eTh/eU & Ra (ppm) & K (\%) \\
\hline 1 & 5 & 12 & 2.4 & 4 & 2.4 \\
\hline 2 & 4 & 15 & 3.8 & 3 & 2.3 \\
\hline 3 & 6 & 21 & 3.5 & 5 & 2.6 \\
\hline 4 & 8 & 25 & 3.1 & 7 & 2.8 \\
\hline 5 & 10 & 20 & 2 & 6 & 2.6 \\
\hline 6 & 15 & 31 & 2.1 & 5 & 2.7 \\
\hline 7 & 16 & 40 & 2.5 & 6 & 1.9 \\
\hline 8 & 15 & 32 & 2.1 & 5 & 1.7 \\
\hline 9 & 6 & 17 & 2.8 & 4 & 1.6 \\
\hline 10 & 5 & 12 & 2.4 & 3 & 1.5 \\
\hline 11 & 4 & 10 & 2.5 & 3 & 1.4 \\
\hline 12 & 4 & 9 & 2.3 & 5 & 1.1 \\
\hline 13 & 5 & 8 & 1.6 & 4 & 1.2 \\
\hline 14 & 3 & 7 & 2.3 & 3 & 1.1 \\
\hline 15 & 5 & 6 & 1.2 & 4 & 1.2 \\
\hline Min. & 3 & 6 & 1.2 & 3 & 1.1 \\
\hline Max. & 16 & 40 & 3.8 & 7 & 2.8 \\
\hline Aver. & 7.6 & 21.5 & 2.2 & 4.2 & 1.8 \\
\hline
\end{tabular}

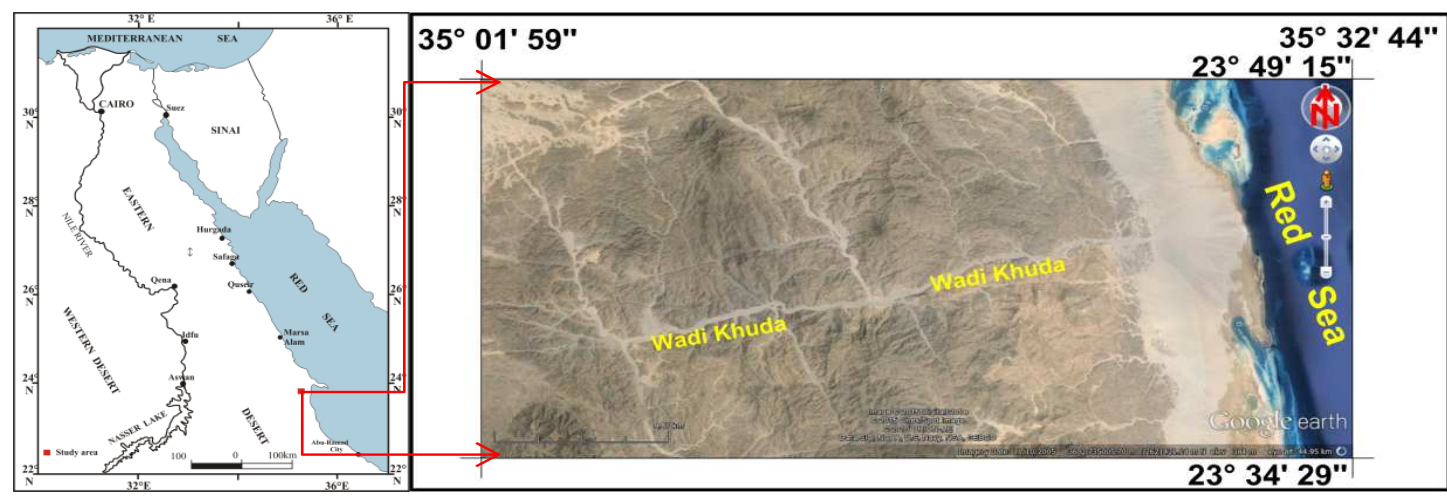

Figure 1 Google image, and Location map of the Wadi Khuda area.

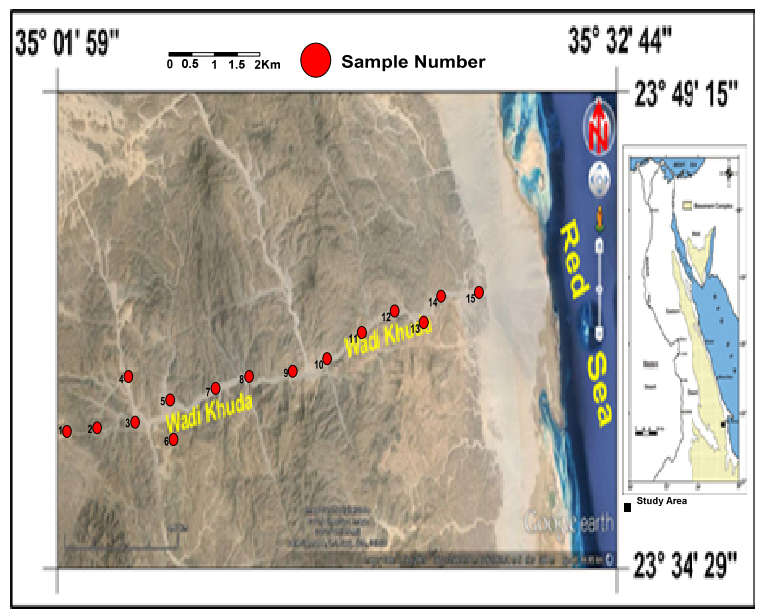

Figure 2 Showing the distance between sampling locations and variation in elevation of the sampling stations along Wadi Khuda. 
Figure 3 Geologic map of Wadi Khuda area showing the location of the collected samples in the study area, modified after EGSMA (1992).

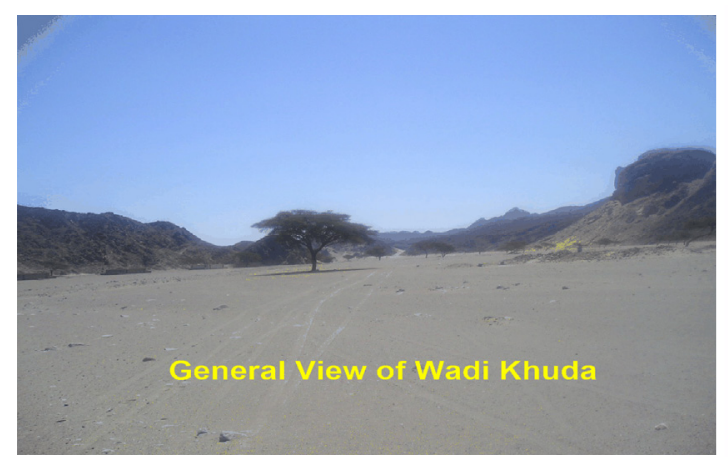

a)

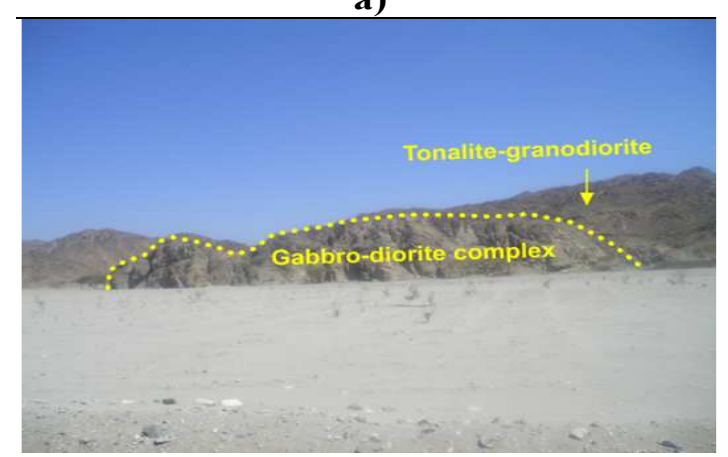

c)

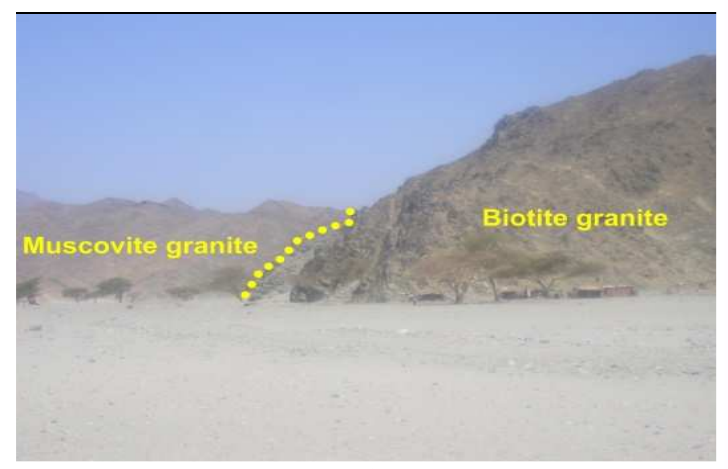

e)
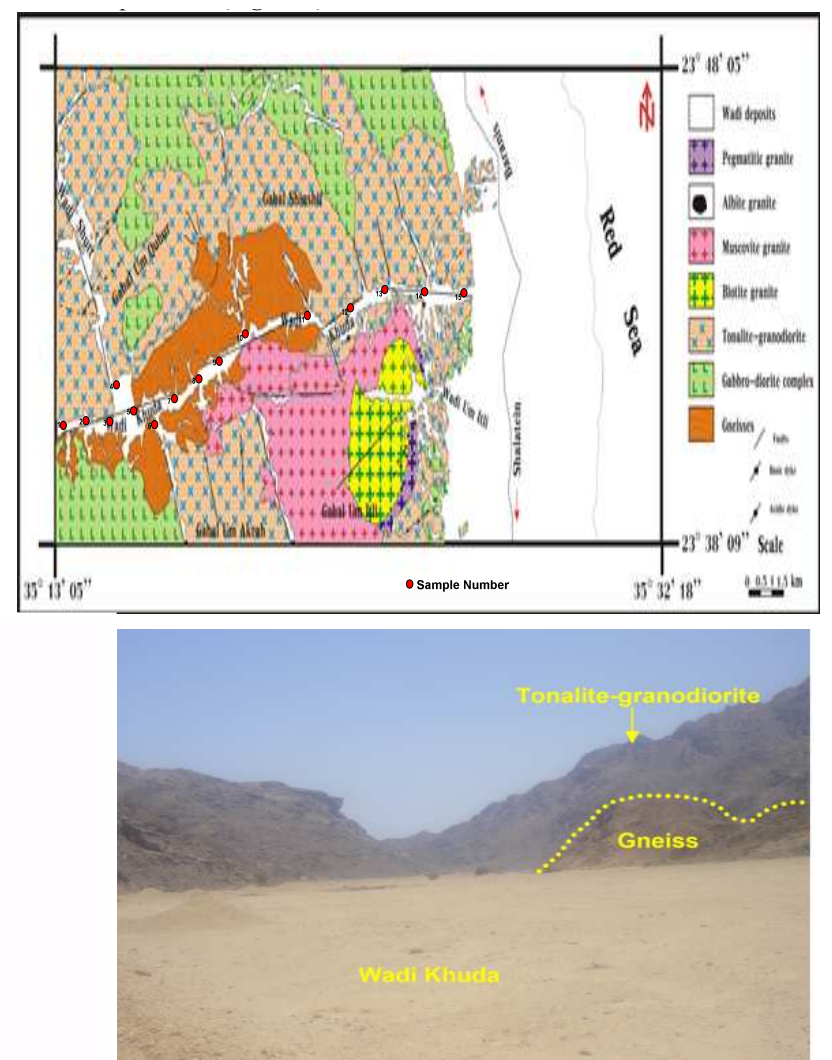

b)

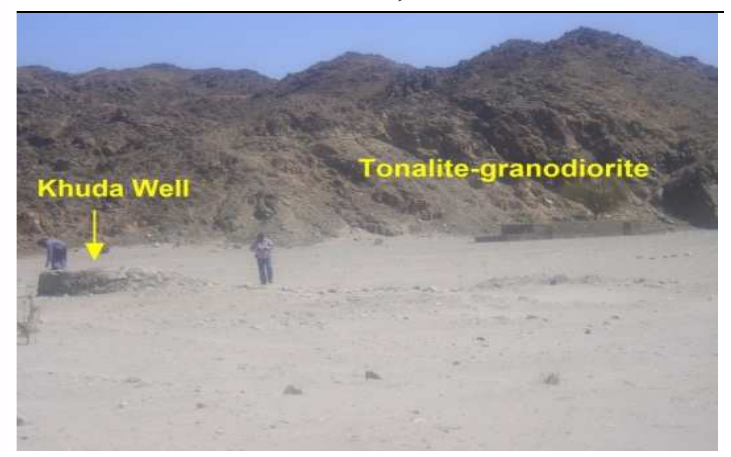

d)

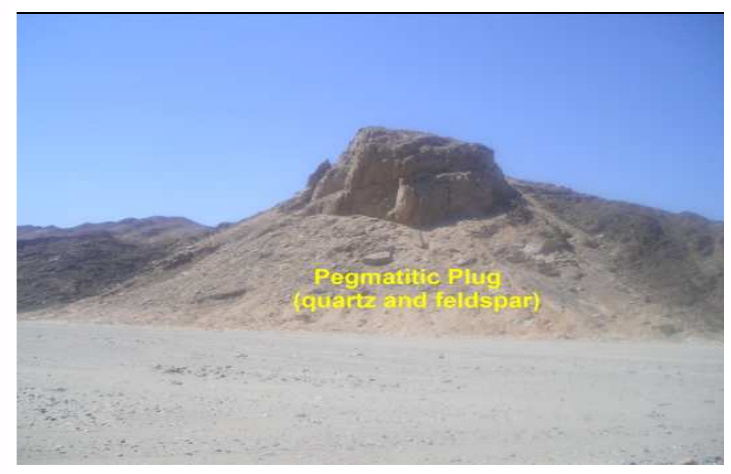

f)

Figure 4 a) General view of Wadi Khuda. b) Intrusive sharp contact between tonalite-granodiorite and gneisses at Wadi Khuda, c) Intrusive contact between gabbro-diorite and tonalite-granodiorite at Wadi Khuda. d) Large extention of tonalite-granodioriteatWadi Khuda, e) Intrusive contact between biotite granite muscovite granite south Wadi Khuda. f) Pegmatitic plugs observed in muscovite granite near the contact with the older granitoids. 
a)

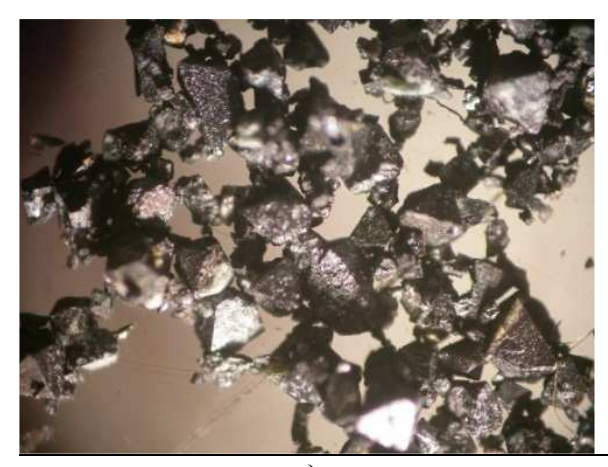

c)

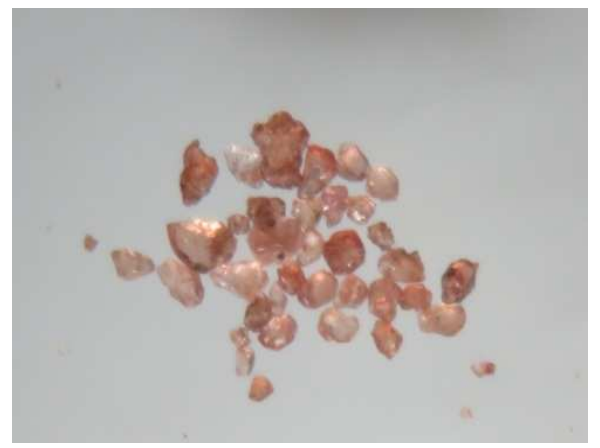

Figure 5: Photomicrographs of the recorded a) Magnetite b) Ilmenite c) Garnet d) Sphene

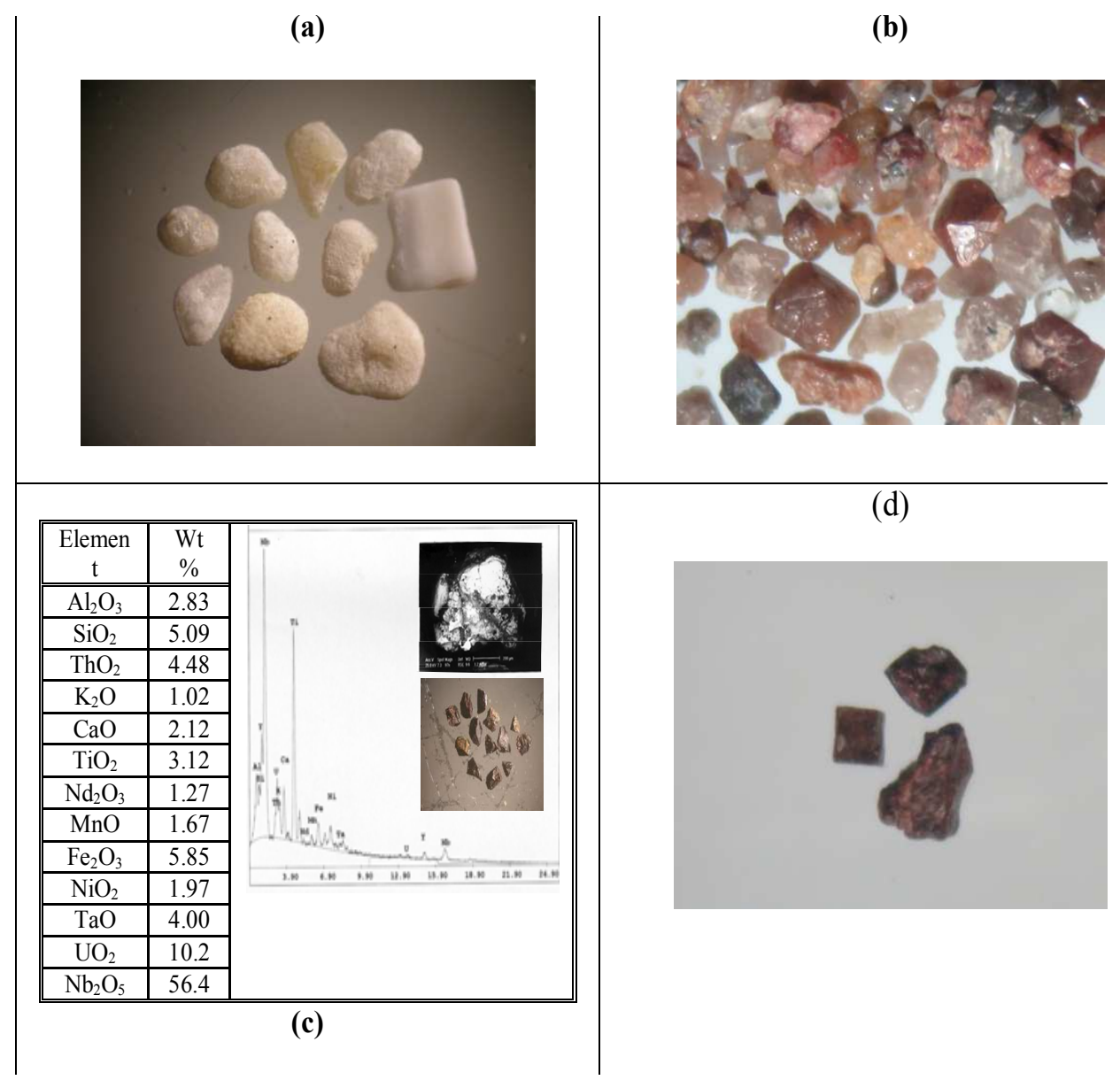

Figure 6: Photomicrographs of the recorded a) Flourite b) Zircon c) EDX and BSE of composite grain of Samarskite d) Thorite b)
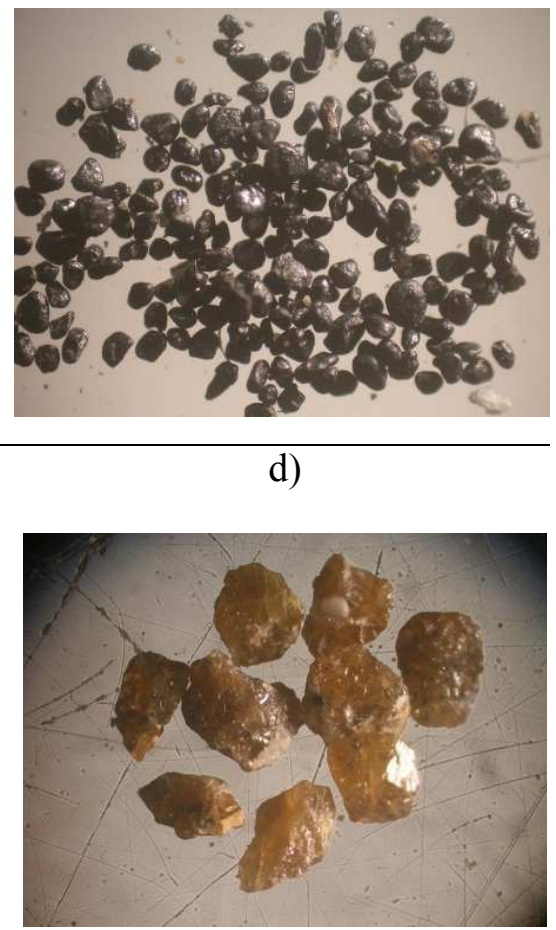

(b) 

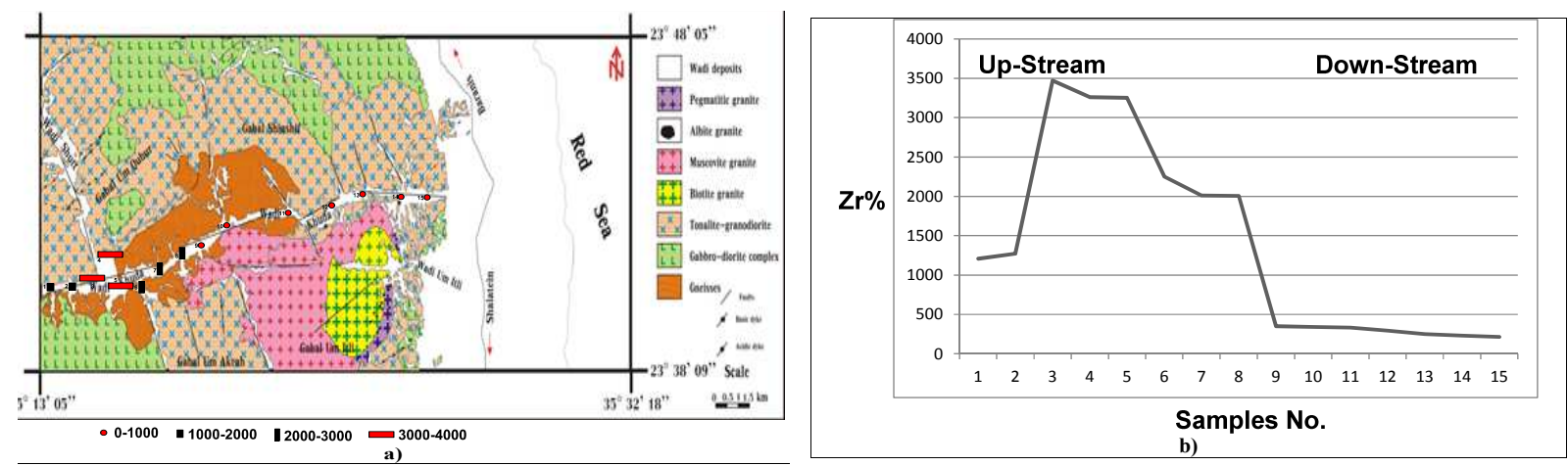

Figure 7 a) The distribution map of zircon in Wadi Khuda b) b) Lateral distribution of zircon in Wadi Khuda
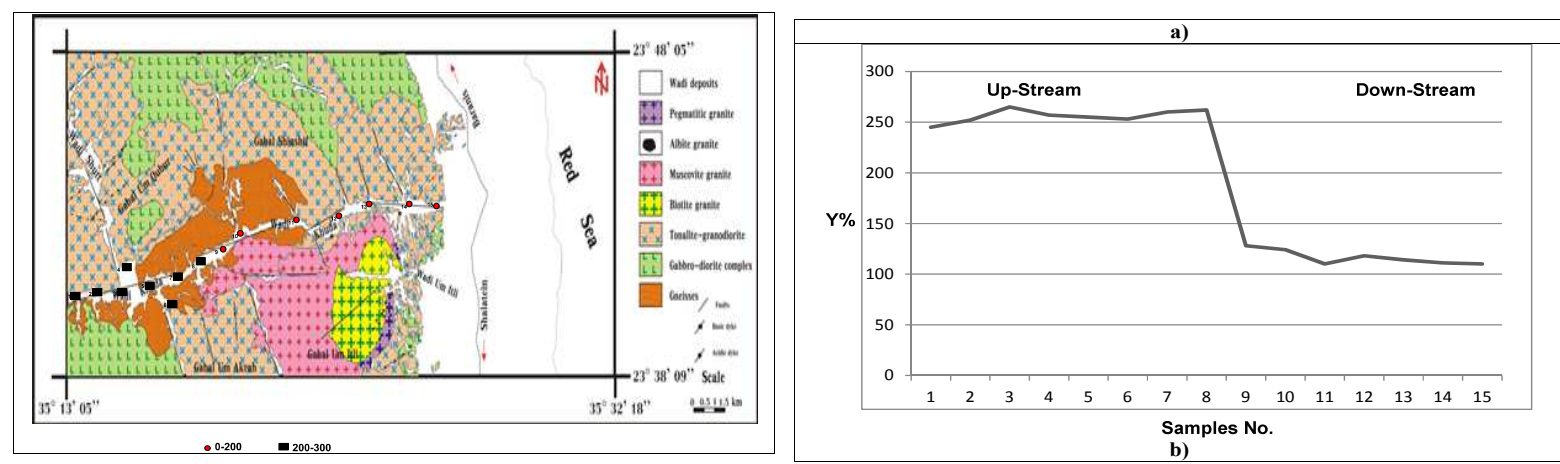

Figure 8 a) The distribution map of yatrium in Wadi Khuda b) b) Lateral distribution of yatriumin Wadi Khuda

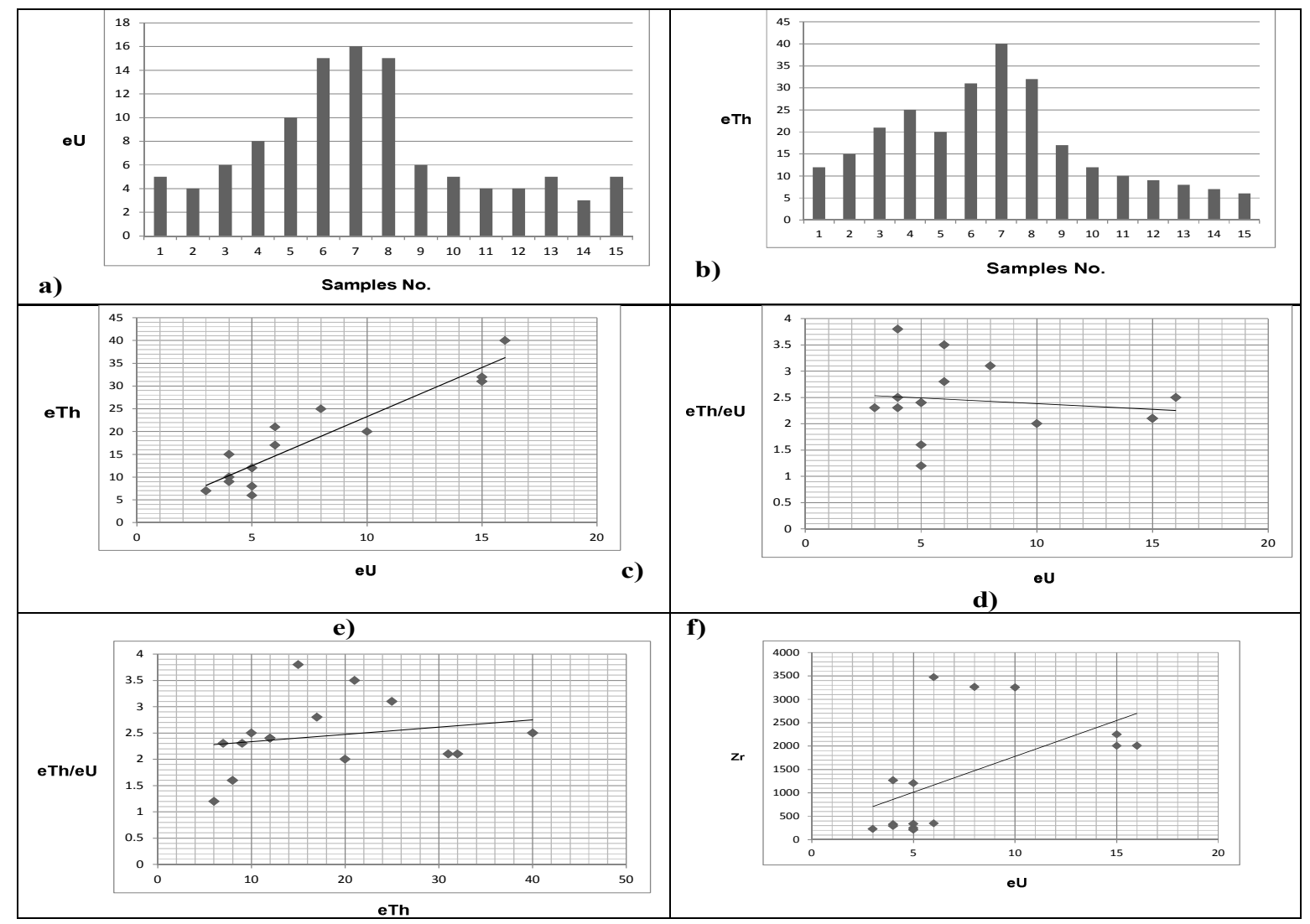

Figure 11: (a) and (b) Histograms showing the distribution of equivalent uranium and thorium ppm. (c) The relationship between equivalent uranium and equivalent thorium. (d) The relationship between eU and $\mathrm{eTh} / \mathrm{eU}$ variation diagram for the stream sediments. (e) The relationship between $\mathrm{eTh}$ and $\mathrm{eTh} /$ eU variation diagram for the stream sediments. (f) The relationship between $\mathrm{eU}$ and concentration of $\mathrm{Zr}$ minerals. 
and concentration of these elements are related to bedrock lithology, where thorite and samarskite show variable values at the entrance of Wadi Khuda correspond well with the occurrence of the pegmattic granite, while the transparent and colored zircon show high concentration, correspond well with the occurrence of the muscovite granite and pegmatitic granite at Wadi Khuda, fluorite, titanite, and garnet show different values and different proportion all over the Wadi. Gamma-ray spectrometry technique shows that the highest radioactivity level is restricted to the area at the northern part of Wadi Khuda rather than the southern part due to the enrichment of the stream sediments by $\mathrm{Zr}$ or Ti-bearing minerals such as zircon, garnet and sphene.

\section{REFERENCES}

Ball, J. 1912:The geography and geology of south eastern Egypt. Geol. Surv., Cairo. P. 394.

El Afandy A.H., Abu Halawa A. and Kandil M. K. 2006: Heavy mineral potentiality of beach placer deposits of south rasbanas, red sea coast, egypt.

El Alfy, Z.; Bagddady, M.; Awaga, G.; Morsei, A.; Ramadan, T. and Abdallah, M. A. 1994:Geochemical exploration of Elba - Gerf area south Eastern Desert , Egypt, Geol. Surv., Cairo ( unpublished report ).
EGSMA, 1992: Geologic map of Baranis Quadrangle, scale 1:250 000. Egyptian Geological Survey, Egypt.

Hume, W.F. 1934:Geology of Egypt. II. The fundamental Precambrian rocks of Egypt and Sudan : Part I, The metamorphic rocks : $1-300$, Part II, The later plutonic and minor intrusive rocks : 301- 688, Part III, The minerals of economic value : 689 - 900, Geol. Surv. Egypt.

Hunting Geology and Geophysics Ltd, 1967: Assessment of the mineral potential of the Aswan Region, United Arab Republic, Photogeological Survey: U.N. Development Programme and U. A. R. Regional Planning of Aswan, 137 P.

Ivanovich, M. 1994:Uranium series disequilibrium: concept and applications. Radiochem. Acta, Vol. 64, P. 81:94.

Langmuir, D. 1978:"Uranium solution-mineral equilibria at low temperatures with application to sedimentary ore deeposites". Geochem. Cosmochim. Acta., V. 42, P. 547.

Matolin, M., 1990:A report to the Government of the Arab Republic of Egypt "Construction and use of spectrometric calibration pads", Egypt/4/030-03, Laboratory Gamma Ray spectrometry

Milner, H. B. 1962:Sedimentary petrography. V, II, George Allen \&Unwin, Ltd., London. pp. 15-205.

Raslan M. F., Ali M. A. and El-Feky M. G. 2010: Mineralogy and radioactivity of pegmatites from South Wadi Khuda area, Eastern Desert, Egypt. Chin.J.Geochem. (2010)29:343-354

$$
\begin{aligned}
& \text { هذه الدر اسة تهتم (تركز على) جيو اوجية ومعدنبة و اشعاعية رواسب و ادى خداع-جنوب الصحر اءع الثرقية ـمصر. }
\end{aligned}
$$

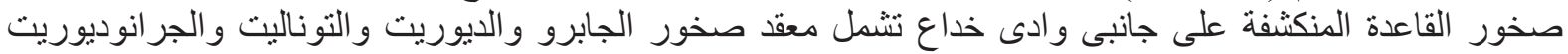

$$
\begin{aligned}
& \text { و المونزوجر انيت و الالبيت جرانيت. }
\end{aligned}
$$

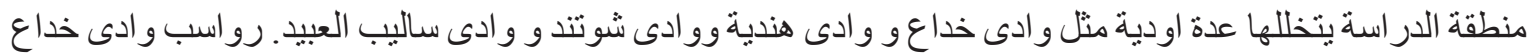

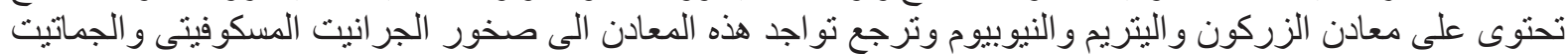

$$
\begin{aligned}
& \text { التداخل فى صخور الجرانيت. } \\
& \text { المعادن الثقبلة المتو اجده برواسب و ادى خداع تتمثل بمعادن الماجنتيت والالمنيت و الزركون و الثوريت و التبتانيت }
\end{aligned}
$$

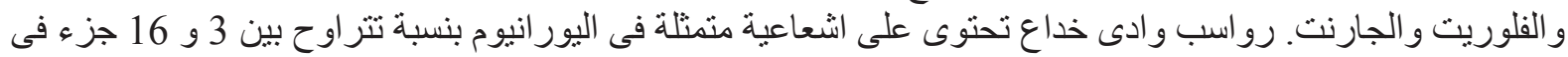

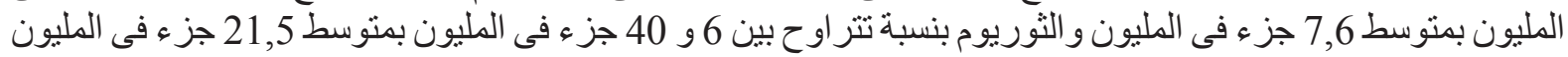

$$
\begin{aligned}
& \text { و الر اديوم بنسبة 4,2 جزء في المليون و البوتاسيوم بنسبة 1,8 \% }
\end{aligned}
$$

